\title{
Macarena Barahona Riera, Mesoamérica ${ }^{1}$
}

\section{Mía Gallegos Domínguez²}

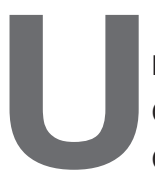

Recepción: 17 de junio de 2015 / Aprobación: 19 de octubre de 2015

na historia cruenta, la tortura, la exclusión, la pobreza, las masacres que no culminan. Esa es la tradición en esta zona del mundo desde tiempos inmemoriales. $Y$ ese es precisamente el nombre que Macarena Barahona le ha puesto a su nuevo poemario: Mesoamérica. De ahí que la poeta nos invita a adentrarnos por los meandros de una geografía y sus rituales de muerte, tal y como lo evoca la portada del libro. Se rinde culto a la muerte, a los desaparecidos, a los flagelados, a los excluidos... La presencia de los muertos está ahí, entre los vivos. Al menos eso es lo que podemos entrever al leer el conjunto de 32 poemas que se agrupan en este tomo. Significativo es el epígrafe que Macarena escogió para iniciar el poemario, dice así:
Ay patria
a los coroneles que orinan tus muros
tenemos que arrancarlos de raíces,
colgarlos en un árbol de rocío agudo
violento de cóleras el pueblo.

El poema tiene autoría, es de Otto René Castillo, poeta guatemalteco, país que ha sido asolado por la barbarie de los militares y las repetidas masacres a lo largo de su historia. Me referí al principio a la importancia que tiene el contexto centroamericano en el poemario, así países como México y La Habana, que guardan una estrecha relación con todo el poemario, son parte del espacio que se recorre, no a la manera de una turista, sino de una mujer en vigilia.

El primer poema que lleva el título de Centroamérica da cuenta de los militares, del espanto, de la pesadilla más que del sueño y dice la poeta que hay seres que ya no poseen ni siquiera un rostro.

Nos habla de la Centroamérica que fue epicentro de la Guerra Fría, de esta región del mundo asolada por las botas militares, por la represión, por los asesinatos y los desaparecidos. No, no se puede olvidar. En verdad el olvido no es posible, aunque haya pueblos, como el salvadoreño, por ejemplo, que han logrado mantener fuera los desmanes del ejército. Los muertos, los desaparecidos están ahí. Fantasmas que no se doblegan recorren esta

1 Costa Rica: B.B.B. Producciones, 2014.

2 Costarricense. Es poeta y periodista. En la actualidad imparte cursos de Técnicas de Comunicación en la Universidad Internacional de las Américas (UIA). Correo electrónico: miagallegosdom@hotmail.com 
nuestra Mesoamérica. Del único lugar de donde no se puede huir es de la conciencia propia y colectiva.

El segundo poema nos presenta imágenes de El Salvador. Huele a sangre, se vislumbran los huesos, sigue el cruento ritual. Ahí está la lluvia que humedece pero que no hiere. Ahí siguen las mujeres portando sus cestas en las calles. Hay luz, hay sol. Sigue la vida pese a los repetidos genocidios que ha vivido esa pequeña nación. En el tercer poema, Macarena se transforma, experimenta ella la tortura vivida por cientos de seres y dice así:
Tengo miedo.
Que me arranquen las piernas y me quede sin seños
Miedo
Que con clavos hagan de mí un quejido de muerte
Que me saquen los ojos y ya no sepa del sol
De la electricidad en las venas
De las miradas de ellos y sus muecas
Que mi piel sea una herida y ya no pueda sangrar
Tengo miedo
No quiero que duela el vientre cuando reviente contra el suelo
No quiero que me quede sin brazos
No quiero que me corten la cabeza en mil pedazos
Tengo miedo
De acordarme siempre quiénes eran ellos.

Este es un poema valiente, en este rememora a todas las mujeres masacradas en países como El Salvador, Honduras, Nicaragua, Guatemala, México... El culto a la muerte, más no nos habla la autora de la muerte como un símbolo, sino como una certeza, una realidad que golpea, que vulnera, que arde, que duele. Y el miedo, el terror como forma de represión y el sentimiento de verse despojado, herido, menguado, acabado. De particular belleza es el poema titulado Catedral de San Salvador, dedicado a Monseñor Romero que a continuación reproduzco:
Se reinicia el odio
Se mueven las flores
Somos la vida
De un marzo
azul cósmico
Que asesinaron en la Iglesia.

Sí, la vida se renueva aunque hayan asesinado al prelado, pero vuelve también la sangre y vuelve la muerte, como si la historia se repitiera incesante y cíclicamente. Por cierto que Macarena cuenta con un estilo muy particular, no nos cuenta historias de sangre, hace alusiones a una realidad violenta, cargada, cruel y atroz.

Una enorme fuerza despliega Macarena en el poema titulado Carta a Roberto Castellanos Braña, quien, como dice la autora, fue asesinado un día de 
marzo de 1980 en San Salvador. Aquí nos da cuenta la autora de uno más entre los cientos de hechos sangrientos que despojaron a esa nación centroamericana durante la guerra civil que duró más de 12 años. Y es que en El Salvador la violencia se reitera. Ha habido a lo largo de su historia genocidios, matanza y despojo de los indígenas, la cruel presencia de un ejército, así como de una clase dominante y oligarca que gobierna con estas bestias.

Así, a mansalva, fue asesinado Roberto Castellanos Braña y así muchísimos nombres más de hombres, mujeres, religiosos, civiles a quienes los militares ultimaron. Resplandeciente caballero, es uno de los nombres con que Macarena alude al amigo masacrado. Mas ella intenta quedarse unos instantes en su vida para prolongar lo que ya la muerte truncó. Reproduzco el final del poema porque es el sentir de la poeta y lo que repetimos los lectores sin cesar:

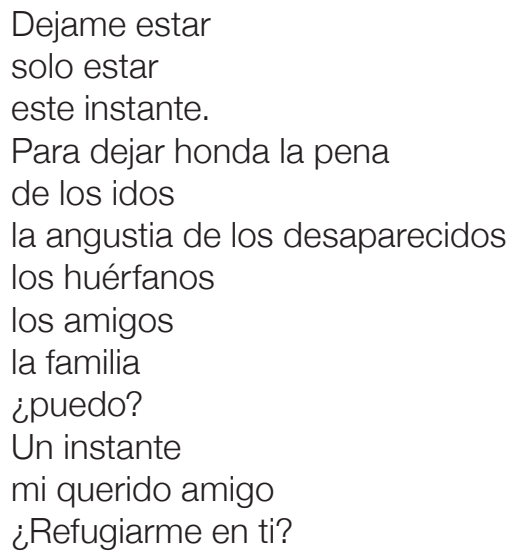

Pese a que el tema central del libro es el culto a la muerte, en todo el poemario abundan los poemas de amor. No me referiré a todos ellos, pero quiero rescatar las siguientes imágenes que aparecen en el poema Uñas Rojas.

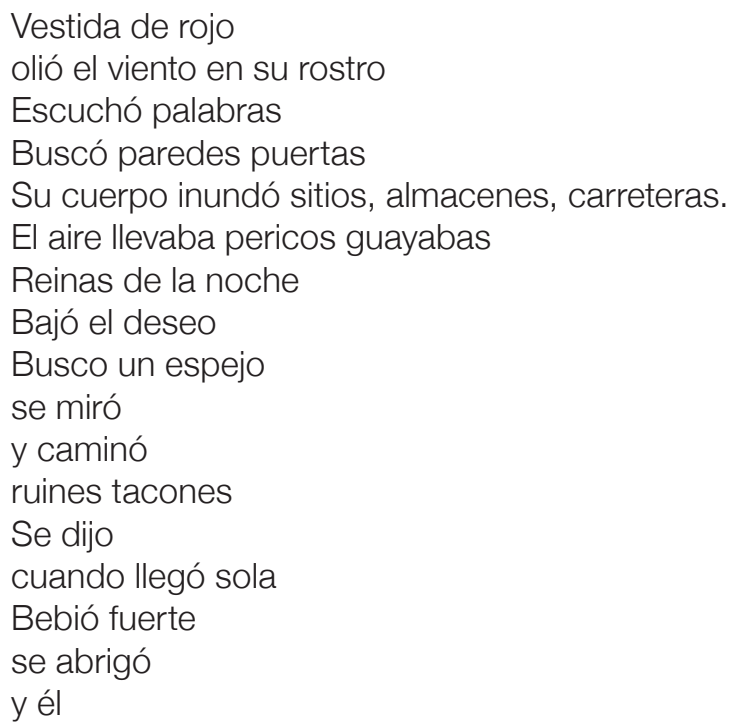


en sus uñas rojas le escribió desátame el nudo de la piel desátame tu olor quiero el corazón de tu sexo quiero mis pezones que ardan ¡oh melancolía! ¡oh melancolía!

Este es un poema contundente, como lo son todos los poemas del libro, mas en este en particular, la sombra del amor está atravesada por la melancolía. La alusión al color rojo forma parte de las figuras transgresoras que abundan en el poemario. La mención a las partes del cuerpo femenino como el corazón del sexo y los pezones nos hablan de una pasión real, vivida y vivificante. Llama la atención que la poeta en ningún caso idealiza realidades, se trata de una poesía concreta. No se da en todo el tomo un ocultamiento de la existencia, se nombra, se alude, no se describe, sino que nos va llevando por una existencia colmada de certezas, de preguntas retóricas que nos obligan a meditar sobre esta presencia cercana de la muerte, por estos rituales de sangre, por estos escenarios donde la violencia es ancestral y atávica.

Al final del libro, Barahona reproduce un poema que resume su biografía y que acentúa su pertenencia a esta zona del mundo. Soy hembra, dice la autora y en esa genealogía hace un recuento de sus orígenes americanistas al evocar figuras indígenas como La Malinche y Dulcehé. Esta hembra se transfigura con la trenza inmensa de una india que conoce la resistencia, es quien resiste, quien no se doblega.

Mesoamérica recoge la voz de una poeta con conciencia revolucionaria, observadora, contestataria. Es un libro que pertenece a la resistencia, al poder indoblegable de los pueblos. 